\title{
Pelaksanaan Program KKN Berbasis Lingkungan, Literasi dan Kewirausahaan di MA Darul Ulum Karangpandan
}

\author{
Mochamad Dai Robi *1, Yudi Purwo Satya S ${ }^{2}$, M. Asyrul Zulmi ${ }^{3}$, Abdul Kodir Jaenuri ${ }^{4}$, \\ Malih Fakhruddin ${ }^{5}$, Tristan Rokhmawan ${ }^{6}$ \\ 1,2,3,4,5,6STKIP PGRI Pasuruan; Jl. Ki Hajar Dewantara No.27-29, Kota Pasuruan, Jawa Timur \\ e-mail:*1mochamaddairobi@gmail.com
}

Informasi Artikel

Diterima Redaksi: 5 Mei 2020

Revisi Akhir: 30 Mei 2020

Diterbitkan Online: 1 Juni 2020

Kata Kunci:

Kewirausahaan, KKN, Lingkungan, Literasi

\section{PENDAHULUAN}

Program Kuliah Kerja Nyata (KKN) adalah salah satu wujud pendidikan pengabdian kepada masyarakat. Melalui program KKN ini mahasiswa mendapatkan pengalaman belajar untuk hidup di tengahtengah masyarakat. Zuliyah (2017: 2) menyatakan bahwa kuliah kerja nyata adalah bentuk pendidikan dengan cara memberikan pengalaman kepada mahasiswa untuk hidup diantara masyarakat dan secara langsung mengidentifikasi serta menangani masalahmasalah yang dihadapi. Pada prinsipnya KKN merupakan suatu bentuk kegiatan pengabdian kepada masyarakat yang dilakukan perguruan tinggi sebagai upaya untuk menerapkan ilmu yang telah didapat.
Abstrak

Tim pelaksana KKN di MA Darul Ulum Karangpandan melaksanakan 3 program, antara lain progam lingkungan, program literasi dan program kewirausahaan. Masalah yang dihadapi adalah kurangnya sikap kepedulian terhadap lingkungan, pasifnya Gerakan Literasi Sekolah dan kurangnya wadah di bidang kewirausaan di sekolah. Pemecahan masalah yang dapat dilakukan dengan pendampingan yaitu memberikan pengetahuan, pemahaman, dan pelatihan perilaku. Program lingkungan meliputi kegiatan sosialisasi tanaman toga, sosialisasi pembuatan pot, edukasi tentang teknik static solution culture, sosialisasi penggolongan sampah dan pengadaan taman sekolah. Program lingkungan bertujuan untuk menumbuhkan sikap peduli terhadap kearsian lingkungan di Sekolah. Program Literasi meliputi pembuatan mading, administrasi perpustakaan, identitas kelas dan desain grafis. Program literasi mampu meningkatkan kesadaran terhadap pentingnya gerakan literasi sekolah. Program kewirausahaan meliputi pelatihan pembuatan produk, pelatihan pemasaran produk dan pelatihan manajemen keuangan. Program kewirausahaan berguna dalam meningkatkan kesadaran akan pentingnya kewirausahaan yang melibatkan siswa agar mereka merasakan manfaatnya secara langsung. Metode kegiatan menggunakan penyuluhan atau sosialisasi, dan metode seminar loka karya. Pada akhirnya Tim KKN STKIP PGRI Pasuruan mampu membuat sekolah di pinggir proyek jalan tol Pas-Pro ini menjadi lebih sejuk.

Program KKN memiliki banyak manfaat terutama bagi mahasiswa. Sutrisno (2019: 3) Menyatakan bahwa kuliah kerja nyata bermanfaat sebagai sarana untuk menambah pengetahuan, pengalaman serta penerapan ilmu yag diperoleh, sarana untuk melatih kedisiplinan dan tanggung jawab dalam menjalankan pekerjaan, sarana meningkatkan keterampilan dan kemampuan. Bagi mahasiswa KKN dapat menjadi pengalaman baru yang bisa menambah pengetahuan, kemampuan dan kesadaran dalam hidup bermasyarakat. Kuliah Kerja Nyata di STKIP PGRI Pasuruan merupakan program yang wajib dikuti bagi mahasiswa STKIP PGRI Pasuruan. Dalam program KKN ini setiap tim yang terdiri dari beberapa mahasiswa 
dikirim ke lembaga pendidikan yang berbasis SMA/ MA/ SMK untuk melaksanakan pengabdian. Salah satu lembaga pendidikan yang menjadi sasaran program KKN adalah MA Darul Ulum Karang Pandan.

Berdasarkan hasil observasi terhadap lingkungan sekolah diketahui bahwa kondisi lingkungan sekolah kurang rindang, lahan yang gersang dan struktur tanah yang tidak subur sehingga membutuhkan penanganan yang baik. Untuk itu kami berupaya untuk melakukan pemulihan, pemeliharaan dan memperbaiki kondisi lahan agar dapat berfungsi dengan baik.

Harryanto (2017: 1) menyatakan bahwa penghijauan dilakukan untuk memulihkan, memelihara dan meningatkan kondisi lahan agar dapat berproduksi secara optimal, baik sebagai pengatur tata air atau pelindung lingkungan. Dari hasil observasi juga ditemukan bahwa terdapat beberapa lahan kosong tanpa tumbuhan, kurangnya fasilitas pembuangan sampah yang memadai dan kurangnya edukasi warga sekolah tentang kebersihan lingkungan.

Adapun kekurangan-kekurangan tersebut ialah mading tidak teratur dan terkesan kurang menarik sehingga minat baca siswa juga terpengaruh, struktur pengurus perpustakaan belum terbentuk dan variasi bahan baca sedikit, belum adanya identitas kelas, kurangnya penggunaan IT (Design Graphic) dalam gerakan literasi di sekolah MA Darul Ulum Karangpandan.

Menurut Faizah, dkk. (2016) Gerakan Literasi Sekolah adalah kemampuan mengakses, memahami, dan mengguanakan sesuatu secara cerdas melalui berbagai aktivitas, antara lain membaca, melihat, menyimak, menulis dan berbicara. Dari pernyataan tersebut dapat disimpulkan bahwa kegiatan literasi dilaksanakan untuk memicu minat baca peserta didik serta meningkatkan keterampilan membaca, menulis, mendengar serta berbicara dan juga mapan dalam bidang IT.

Maka dari itu untuk mengatasi masalah - masalah yang telah ditemukan dari hasil observasi, kami membuat beberapa program kegiatan. Program kegiatan tersebut antara lain, program gerakan lingkungan, program gerakan literasi sekolah dan program kewirausahaan. Dalam melaksankan program-program ini tim melibatkan warga sekolah khusunya para siswa. Dan diharapkan dengan terlaksannya program tersebut masalah dapat teratasi dengan baik.

Program gerakan lingkungan adalah suatu program yang dilakukan untuk mengatasi masalah-masalah yang terdapat pada lingkungan persekolahan. Program ini meliputi beberapa kegiatan. Kegiatankegiatan tersebut antara lain Sosialisasi Pembuatan Sarana Tanaman Toga. Kegiatan ini bertujuan untuk mengenalkan tanaman Toga, manfaatnya dan cara penanamannya kepada para siswa. Kemudian terdapat kegiatan sosialisasi Pembuatan Pot Animal. Dalam kegiatan ini siswa diajarkan untuk membuat pot tanaman dengan memanfaatkan limbah ataupun bahan bekas. Adapun bahan yang digunakan adalah botol plastic air mineral.

Kegiatan selanjutnya adalah edukasi kepada seluruh warga sekolah tentang teknik Static Solution Culture. Static Solution Culture memiliki pengertian budidaya hidroponik dengan air statis yang mana airnya diam dan tidak mengalir. Berikutnya adalah sosialisasi pengadaan sampah organic dan nonorganic. Kegiatan yang terakhir adalah Pengadaan Taman Sekolah. dalam kegiatan ini Tim KKN STKIP PGRI Pasuruan dan warga sekolah bergotong royong untuk membersihkan lingkungan sekitar dan membuat taman yang terletak di depan sekolah.

Program gerakan literasi sekolah dilaksanakan dengan tujuan untuk menumbuhkembangkan budi pekerti peserta didik melalui pembudayaan ekosistem literasi sekolah yang diwujudkan dalam Gerakan Literasi Sekolah. Menurut Weidarti dkk, (2016: 7-8) Gerakan Literasi berupaya untuk menjadikan sekolah menjadi organisasi pembelajaran yang literal warganya hingga sepanjang hayat. Dalam program ini terdapat empat kegiatan yang membutuhkan keterlibatan warga sekolah khususnya para siswa. Kegiatan tersebut antara lain Majalah Dinding (MADING), kegiatan Administrasi Perpustakaan dan Desain Grafis.

Kegiatan majalah dinding (MADING) bertujuan untuk mengaktifkan kembali fungsi mading yang mengingatkan betapa pentingnya mading. Hal tersebut didukung 
oleh pernyataan Widodo (1992: 1) yang berbicara peran majalah dinding dalam gerakan literasi sekolah bahwa majalah dinding memiliki peran yang cukup tinggi dalam upaya pembinaan dan pembentukan siswa, baik dalam aspek pengetahuan, kemampuan/keterampilan, bakat dan minat maupun sikap.

Selain itu kegiatan berikutnya adalah Administrasi Perpustakaan. Dalam kegitan ini dibentuk kepengurusan tetap yang menjaga kebersihan dan kerapian dari perpustakaan. Kegiatan selanjutnya adalah Penjenamaan Identitas Kelas (Class Branding). Pemasangan identitas kelas bertujuan memperindah tampilan luar dari ruang kelas itu sendiri. Dan kegiatan yang terakhir adalah Desain Grafis. Dalam kegiatan ini tim menginginkan para siswa juga mapan akan penggunaan IT dalam gerakan literasi.

Program kewirausahaan mencakup indentifikasi peluang-peluang sistem ekonomi dengan kemampuan yang berbeda wirausahawan dalam mencoba untuk memprediksi dan menyikapi perubahan pasar. Program kewirausahaan ini bertujuan untuk memberikan pengetahuan yang lebih luas kepada siswa MA Darul Ulum Karang Pandan agar mempunyai kepribadian wirausaha dan kreatifitas untuk membuat suatu produk yang awalnya belum ada dilingkungan sekolah menjadi ada dan menjadikan suatu produk yang mempunyai nilai jual yang tinggi. Dengan adanya pelatihan siswa dapat meningkatkan tekad dan semangat yang kuat untuk menciptakan suatu produk .

Adapun tujuan diadakannya programprogram tersebut, antara lain Program gerakan literasi sekolah mempunyai tujuan untuk menumbuh dan mengembangkan pengetahuan maupun budaya literasi di sekolah. Program berbasis lingkungan bertujuan untuk menciptakan kondisi yang baik bagi sekolah untuk menjadi tempat pembelajaran. Sedangkan program kewirausahaan bertujuan untuk meningkatkan daya inovasi dan kreatifitas siswa melalui pembuatan produk-produk.

\section{METODE}

MA Darul Ulum Karangpandan adalah salah satu lembaga pendidikan yang menjadi sasaran program KKN STKIP PGRI Pasuruan. MA Darul Ulum Karangpandan terletak di Kecamatan Rejoso, Kabupaten Pasuruan, Provinsi Jawa Timur. Dalam pelaksanaan KKN di MA Darul Ulum Karang Pandan, tim melakukan 3 Program, yaitu Program lingkungan yang fokus untuk mengatasi masalah lingkungan sekolah, program literasi bertujuan untuk meningkatkan budaya literasi sekolah dan Program Kewirausahaan berfokus untuk mengembankgan dan melatih bakat siswa untuk berwirausaha.

Program gerakan peduli lingkungan hidup, Pada tanggal 13 - 15 November 2019, tim melakukan observasi terhadap lingkungan sekolah. Kemudian pada tanggal 16-20 November 2019, tim melakukan penyuluhan kepada seluruh warga sekolah mengenai kepedulian terhadap lingkungan. Kegiatan penyuluhan meliputi sosialisasi mengenai penggolongan sampah sesuai dengan jenisnya serta mendaur ulangnya menjadi barang bermanfaat. Dan tim juga mengedukasi tentang kepedulian terhadap lingkungan khususnya pada tanaman yang berada dilingkungan sekolah, contohnya tanaman toga, pohon mangga, teknik menanam hidroponik. Pada tanggal 21 November-13 Desember 2019 tim KKN beserta warga sekolah bergotong royong membersihkan lingkungan, membuat taman, membuat pot animal dan memasang paranet.

Program gerakan literasi sekolah dimulai pada tanggal 27 November 2019, Tim KKN STKIP PGRI Pasuruan melakukan 3 kegiatan sekaligus, kegiatan pertama adalah perbaikan terhadap mading dengan mengecat dan menghiasnya sesuai dengan tema agar terlihat rapi dan indah. Kegiatan kedua adalah sosialisasi tentang mading. Sosialisasi dilakukanan agar para siswa rajin untuk membuat karya di mading. Kegiatan ketiga adalah sosialisasi tentang duta perpustakaan.

Dan pada tanggal 28 November 2019 tim membuat identitas kelas. Tim memilih nama tokoh wali songo sebagai ientitas kelas. Dalam pembuatan identitas kelas, time menggunakan kayu bekas yang dicat kemudian diberinama dengan stiker. Tim juga memasang infografis di dinding depan kelas dari setiap tokoh. Hal itu bertujuan 
untuk mengenalkan wali songo kepada warga sekolah.

Pada hari itu juga tim pelatihan desain grafis kepada siswa MA Darul Ulum Karang Pandan. Di sana dijelaskan fungsi dari setiap tool yang ada di aplikasi desain, dalam hal ini tim menggunakan Photoshop dan Corel Draw, serta cara bagaimana mendesain yang baik dan benar. Kemudian pada tanggal 30 November 2019 tim melakukan pemilihan duta perpustkaan. Selama kegiatan literasi berlangsung dilakukan Tim juga mengajukan proposal permohonan buku kepada pihak penerbit untuk disumbangkan ke perpustakaan. tim juga menyumbang buku ke perpustakaan sekolah.

Program kewirausahaan dilaksanakan dengan mengadakan sosialisasi dan pelatihan yang diikuti oleh 20 siswa. Dalam kegiatan ini tim menjelaskan bagaimana cara membuatan Es susu jelly dan es sarang burung cincau, apa saja yang dibutuhkan dan bahan-bahannya. Kemudian siswa dibagi menjadi 2 grup untuk mempraktikan pembuatan es sarang burung cincau dan es susu jelly. selanjutnya siswa memasarkan produk yang telah mereka buat kepada warga sekolah untuk melatih keberanian mereka. setelah selesai melakukan pemasaran produk, siswa belajar untuk menghitung manajemen keuangan.

\section{HASIL DAN PEMBAHASAN}

Tim pelaksana KKN di MA Darul Ulum Karangpandan melaksanakan 3 program, antara lain progam lingkungan, program literasi dan program kewirausahaan.

1. Program lingkungan meliputi kegiatan sosialisasi tanaman toga, sosialisasi pembuatan pot, edukasi tentang teknik Static Solution Culture, sosialisasi Penggolongan sampah dan pengadaan taman sekolah. Program lingkungan bertujuan untuk menumbuhkan sikap peduli terhadap kearsian lingkungan di Sekolah.

2. Program Literasi meliputi pembuatan mading, administrasi perpustakaan, identitas kelas dan desain grafis. Program literasi mampu meningkatkan kesadaran terhadap pentingnya gerakan literasi sekolah.

3. Program kewirausahaan meliputi pelatihan pembuatan produk, pelatihan pemasaran produk dan pelatihan manajemen keuangan. Program kewirausahaan berguna dalam meningkatkan kesadaran akan pentingnya kewirausahaan yang melibatkan siswa agar mereka merasakan manfaatnya secara langsung.

\subsection{Gerakan Lingkungan}

1. Program Sosialisasi Tanaman TOGA

Tanaman obat keluarga (TOGA) merupakan tanaman budidaya di rumahan yang berkhasiat sebagai obat. Masih banyak orang yang menggunakan obat tradisional untuk menyembuhkan beberapa penyakit dengan cara menanam tanaman obat keluarga ini. Ada beberapa tahapan yg dapat dilakukan :

a. Persiapkan pupuk kandang dengan pupuk humus di wadah yang kamu sediakan, seperti polybag atau pot kecil.

b. Persiapkan bibit tanaman toga yang sudah kamu siapkan.

c. Tanam bibit tanaman toga ke dalam campuran pupuk yang telah kamu sediakan tadi dan tunggu proses pertumbuhannya.

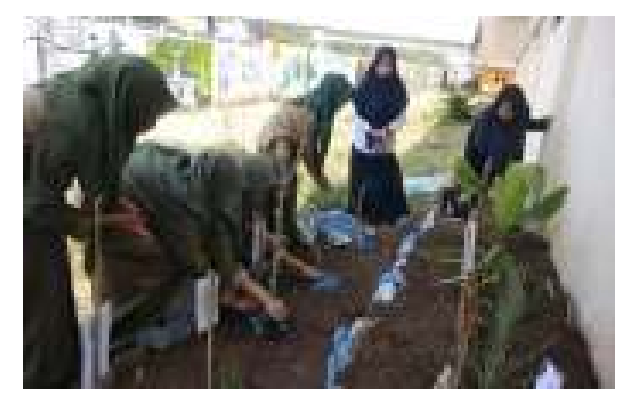

Gambar 1. Sosialisasi Tanaman Toga

2. Program Sosialisasi Pot Animal

Sosialisasi pembuatan pot animal diawali dengan persiapan alat dan bahan. Berikut ini alat dan bahan yang digunakan:

a. Botol plastik bekas,

b. Pisau pemotong/cutter,

c. Cat akrilik,

d. Pensil gambar.

Berikut ini langkah-langkah yang dilakukan dalam pembuatan pot animal adalah sebagai beirkut:

a. Siapkan pola gambar yang akan Anda tempatkan pada botol plastik. Misalnya pola gambar beruang, 
kelinci atau hewan-hewan favorit Anda.

b. Gambar pola tersebut pada botol plastik lalu potong mengikuti gambar polanya.

c. Warnai potongan botol yang telah berbentuk dengan cat akrilik dengan warna dasar putih.

d. Tambahkan dengan cat warna yang sesuai dengan karakter pola yang Anda gambar tadi.

e. Gambarkan mata, hidung ataupun telinga pada polanya agar tampilannya semakin lucu dan tampak seperti kartun.

f. Keringkan sampai catnya tidak melumer dan pot hasil dari botol bekas sudah siap dijadikan hiasan.

g. Untuk menjadi pot hias gantung bisa diberi gantungan tali pada kedua sisinya.

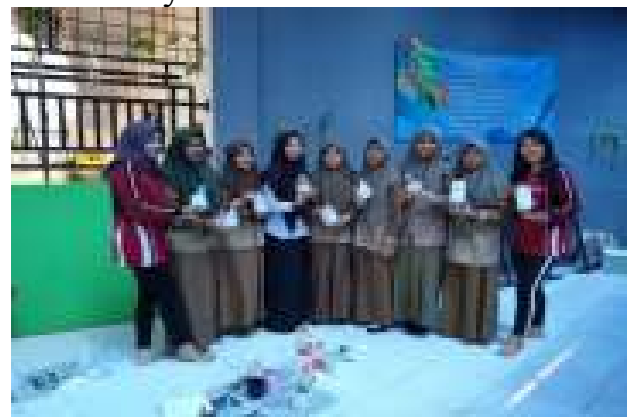

Gambar 2. Sosialisasi Pembuatan Pot Animal

\section{Program Edukasi Teknik Static Solution Culture}

Static Solution Culture memiliki pengertian budidaya hidroponik dengan air statis yang mana airnya diam dan tidak mengalir, merupakan teknik hidroponik yang akarnya secara terus-menerus akarnya tercelup air yang diletakkan pada wadah berisi larutan nutrien. Namun di Indonesia, Static Solution Culture lebih dikenal dengan istilah teknik apung (atau disebut rakit apung) dan sistem sumbu (atau disebut wick system). Untuk ukuran wadah larutan dapat berbeda tergantung pada penggunaan dan ukuran tanaman.

Dalam skala kecil (skala rumah tangga maupun hobi berskala kecil), hidroponik dapat dibuat dengan wadah yang biasanya dipakai di dalam rumah seperti gelas, toples, ember, ataupun bak air. Wadah bening dapat di bungkus dengan Aluminium foil, plastik, cat, atau material lain yang menolak cahaya (membuat cahaya tidak bisa masuk) agar tidak tumbuh lumut. Penutup wadah air dilubangi dan diisi tanaman, disitu dapat diisi satu atau beberapa netpot tanaman untuk setiap wadah air.

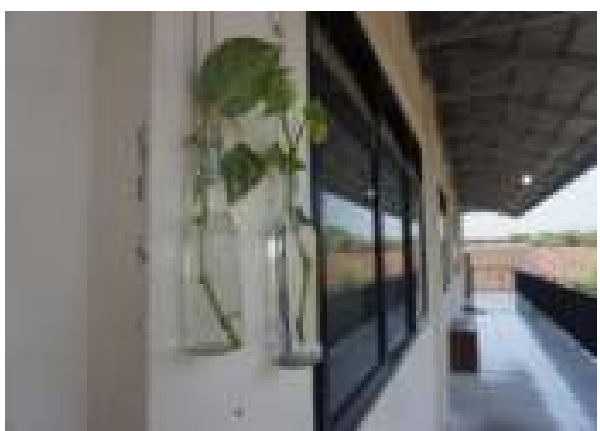

Gambar 3. Static Solution Culture

4. Program Pengelolaan Sampah Organik dan Nonorganik

Sampah adalah sisa buangan dari suatu produk atau barang yang sudah tidak digunakan lagi, tetapi masih dapat di daur ulang menjadi barang yang bernilai. Sampah organik adalah sampah yang berasal dari sisa mahkluk hidup yang mudah terurai secara alami tanpa proses campur tangan manusia untuk dapat terurai.

Sampah organik bisa dikatakan sebagai sampah ramah lingkungan bahkan bisa diolah kembali menjadi suatu yang bermanfaat bila dikelola dengan tepat contoh sisa sayur, buah yang busuk, kayu, ranting pohon, dan daun-daun kering. Sampah anorganik adalah sampah yang sudah tidak dipakai lagi dan sulit terurai jika tertimbun di tanah dapat menyebabkan pencemaran tanah karena tergolong zat yang sulit terurai dan akan tertimbun dalam tanah dalam waktu lama, ini menyebabkan rusaknya lapisan tanah. Contohnya adalah botol/ kaleng minuman, ban bekas, besi, kaca, kabel, barang elektronik, bohlam lampu dan plastik.

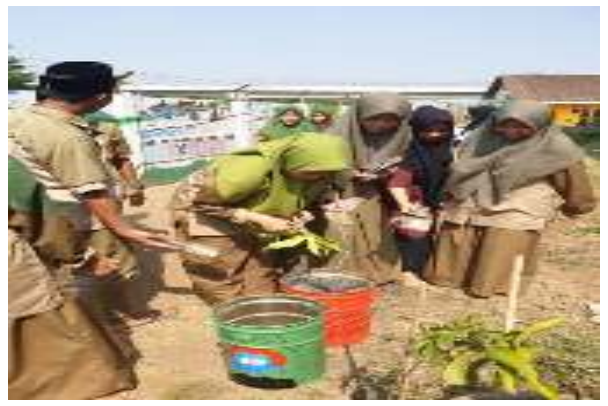

Gambar 4. Pengelompokan Sampah 
5. Program Taman Sekolah

Taman MA Darul Ulum terdapat batu taman, jalan setapak, peletakan batu alam, terdapat 2 jenis tong sampah dengan warna berbeda-beda, ornamen bebatuan dan semua itu termasuk dalam bidang keras. Sedangkan dalam bidang lunak seperti tanaman tanaman yang tumbuh disana contohnya cemara, pucuk merah, puring, rerumputan, manga, suruh, lee kwan yu dan banyak tanaman lainnya.

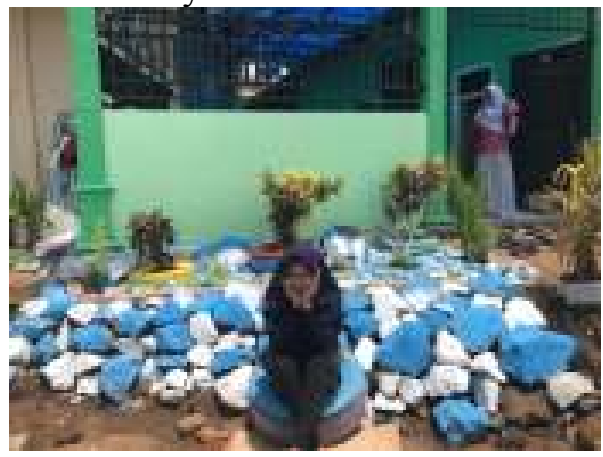

Gambar 5. Hasil Taman Sekolah

\subsection{Gerakan Literasi}

\section{Program Mading Sekolah}

Pembaharuan mading yang melibatkan siswa ini berupaya menstimulus bakat menulis dari siswa dan sebagai trigger kreatifitas siswa agar lebih ditingkatkan lagi. Peranan majalah dinding yang tampak pokok sebagai salah satu fasilitas kegiatan siswa secara fisikal dan faktual serta memiliki sejumlah fungsi, yaitu informatif, komunikatif, rekreatif, dan kreatif. Nursisto (1999: 2-8) mengatakan majalah dinding yang ada di sekolah bermanfaat dalam hal sebagai media untuk membangun kebiasaan membaca, untuk meningkatkan keterampilan menulis, sebagai media komunikasi, sebagai media kreativitas.

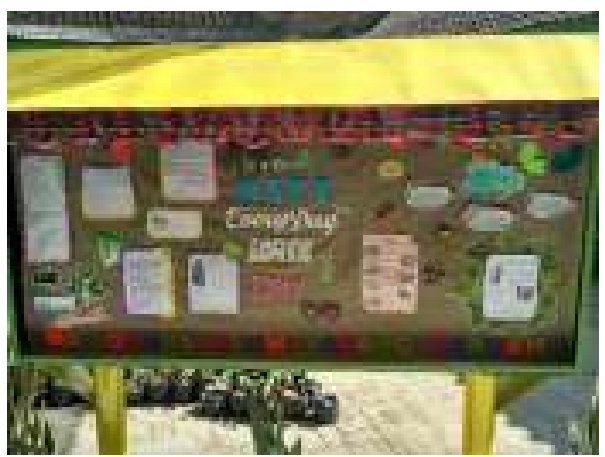

Gambar 6. Hasil Mading Sekolah
2. Program Perpustakaan Sekolah

Program kerja yang selanjutnya adalah penambahan koleksi bahan baca pada perpustakaan MA Darul Ulum Karang Pandan. Untuk kelancaran gerakan literasi sekolah, pengelolaan perpustakaan adalah salah satu hal penting, karena perpustakaan adalah sarana bagi siswa untuk mencari informasi dan wawasan.

Dalam hal ini, tim mengajukan proposal permohonan bantuan buku dari instansi tertentu. Tidak hanya itu, mahasiswa dari tim KKN PGRI Pasuruan di MA Darul Ulum ini berpartisipiasi dalam penambahan koleksi baca. Istilah upaya yang dilakukan oleh tim KKN adalah stock opname. Menurut Yuyu (2010), stock opname terkait dengan kegiatan pengembangan koleksi suatu perpustakaan didasarkan pada profil seleksi dan kebutuhan pengguna akan koleksi perpustakaan tersebut. Tim juga melakukan pemilihan duta perpustakaan untuk membantu mengelola semua keperluan administrasi perpustakaan, dari katalog judul buku sampai pembukuan semua buku yang masuk.

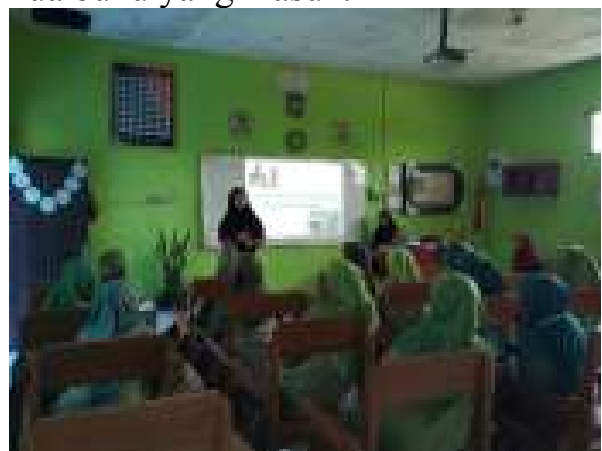

Gambar 7. Penyuluhan Perpustakaan

3. Program Penjenamaan Identitas Kelas

Tim KKN PGRI Pasuruan memberikan penjenamaan identitas kelas dengan namanama Walisongo. Bukan tanpa alasan mendasar, tim memutuskan untuk memberi nama ruang kelas tersebut sesuai jumlah yang ada. Selain itu, Walisongo juga cocok untuk nuansa sekolah yang islami. Pemberian identitas kelas bertujuan untuk menumbuhkan faham dan empati sejarah para siswa terhadap tokoh agama. Empati sejarah juga merupakan suatu alat untuk memahami sejarah. Menurut Yeager dan Davis (1996: 3), "good history offers a window on human character" kerana sejarawan memerlukan empati semasa 
mengemukakan persoalan dan membuat analisis terhadap sesuatu kejadian, tindakan dan pemikiran seseorang tokoh sejarah. Langkah tersebut bertujuan membantu mereka membina makna dan pengertian sejarah.

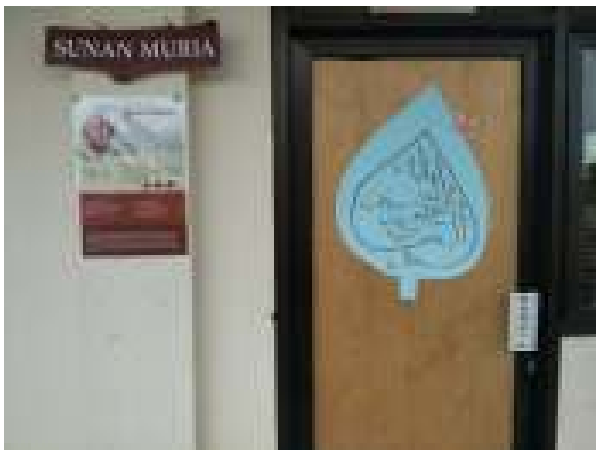

Gambar 8. Penamaan Suatu Kelas

4. Program Pelatihan Desain Grafis

Tahap akhir dari gerakan literasi sekolah dari tim KKN PGRI Pasuruan yaitu desain grafis. Bertujuan agar para siswa memahami penggunaan IT dalam gerakan literasi ini, mengikuti industri 4.0. Means (1993) menyatakan bahwa kebutuhan masyarakat persekolahan untuk memanfaatkan teknologi dalam pembelajaran merupakan bagian dari reformasi pembelajaran. Kebutuhan untuk memanfaatkan teknologi itu mula-mula dipengaruhi oleh fakta-fakta yang terjadi di komunitas luar sekolah (bisnis, pemerintahan, dan masyarakat umum) yang sudah lazim menggunakan teknologi dalam aktivitas berkomunikasi, mencari informasi, dan aktivitas komersial.

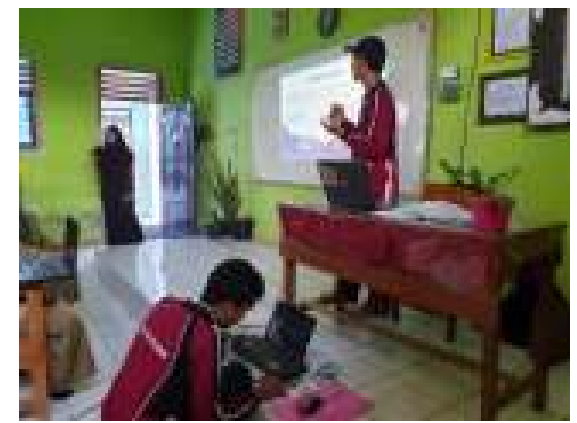

Gambar 9. Lokakarya Desain Grafis

\subsection{Gerakan Kewirausahaan}

1. Program Wirausaha Pembuatan Es

Pelatihan pembuatan es susu jelly dan es sarang burung cincau. Es susu jelly adalah minuman dingin kekinian yang cocok dinikmati saat cuaca panas yang kini telah melanda. Es ini dibuat dari bahan-bahan yang mudah didapatkan. Proses pembuatnya juga sangat mudah di praktikkan oleh siswa dan cara penyajiannya sangat cepat. Mmodal yang dibutuhkan untuk membuat es susu jelly juga sangat sedikit tetapi dapat menghasilkan laba yang menjanjikan.

Berikut ini bahan-bahan yang dibutuhkan dalam pembuatan es jelly:

a. Nutrijelly rasa cocopandan

b. Gula murni

c. Selasih yang sudha direndam air

d. Air minum

e. Gelas plastik

f. Sendok es

g. Sedotan

Berikut peralatan yang dibutuhkan dalam pembuatan es jelly:

a. Wadah

b. Sendok

c. Gunting

d. Panci

e. Centong sayur

f. Kompor

Berikut langkah-langkah dalam pembuatan es jelly:

a. Panaskan panci lalu masukkan air sebanyak 2 liter ke dalam panci lalu masukkan nutrijelly rasa cocopandan dan tambahkan sedikit gula, aduk hingga mendidih setelah mendidih diamkan selama 1 jam agar nutrijelly mengeras.

b. Siapkan baskom lalu masukkan gula, susu dan air ke dalamnya aduk hingga larut dan tercampur.

c. Selanjutnya nutrijelly di potong kecilkecil menggunakan pisau.

d. Siapkan gelas, masukkan nutrijelly, selasi dan air yang sudah campur gula dan susu.

e. Es susu jelly siap dipasarkan.

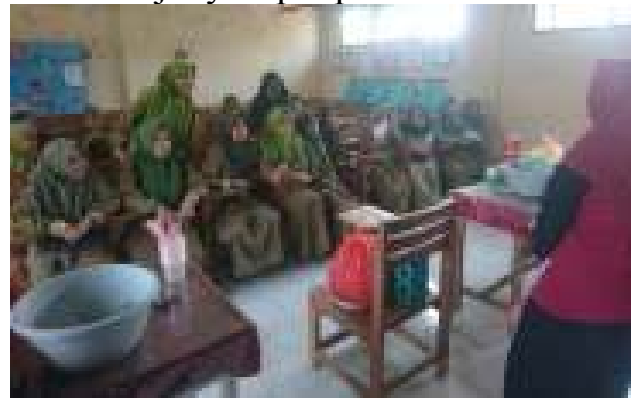

Gambar 9. Demo Masak Pembuatan Es Jelly 
Es sarang burung cincau adalah minuman dengan cita rasa yang menyegarkan. Mengkomsumsi minuman yang sangat segar lebih nikmat apabila di konsumsi saat cuaca panas. Es sarang burung cincau ini sangat mudah proses pembuatannya, cara penyajiannya pun sangat praktis jadi sangat mudah dilakukan dikalangan anak sekolah. Modal yang dibutuhkan untuk membuat es sarang burung sangatlah ekonomis tetapi dapat menghasilkan laba.

Berikut ini bahan-bahan yang dibutuhkan dalam pembuatan es sarang burung cincau:

a. Cincau hitam

b. Gula murni

c. Teh bandul

d. Susu kental manis

e. Air minum

f. Gelas plastik

g. Sendok es

h. Sedotan

Berikut peralatan yang dibutuhkan dalam pembuatan es sarang burung cincau:

a. Wadah

b. Sendok

c. Gunting

d. Panci

e. Centong sayur

f. Kompor

g. Parutan keju

h. Saringan teh

Berikut langkah-langkah dalam pembuatan es sarang burung cincau:

a. Siapkan panci yang berisi air 2 liter, masak air hingga mendidi setelah mendidi masukan the kedalam panci diamkan selama 5 menit.

b. Siapkan baskom dan sarangan teh di atasnya setelah itu saring teh kedalam baskom.

c. Masukkan gula \& susu kental manis kedalam baskom aduk hingga larut.

d. Siapkan baskom yang berisi air gula \& susu dan parutlah cincau hitam kedalamnya.

f. Es sarang burung cincau siap dipasarkan.

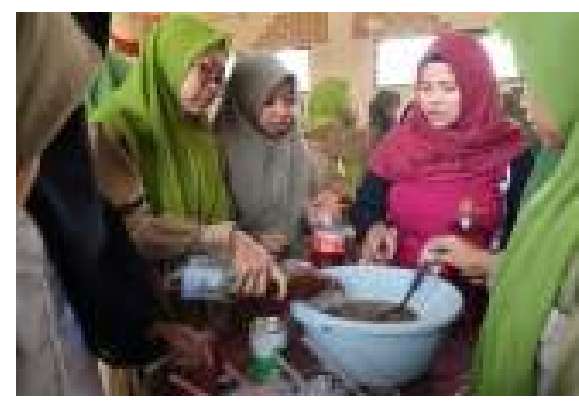

Gambar 10. Demo Masak Pembuatan Es Sarang Burung Cincau

\section{Program Pemasaran Produk Es}

Kegiatan berikutnya adalah melatih siswa untuk memasarkan produk yang telah dibuat. Siswa diajak untuk melakukan pemasaran produk yang telah dibuat dengan cara promosi penjualan kepada warga sekolah dengan melakukan strategi pendeketan kepada pembeli, memberi informasi terkait produk yang dijual dan memberikan penguatan agar pembeli membeli produk yang telah ditawarkan.

Strategi pemasaran adalah keseluruhan program perusahaan dalam menentukan target pasar dan memuaskan konsumen dengan membangun kombinasi elemen dari marketing mix yaitu produk, tempat, promosi, dan harga. (Kurtz, 2008). Strategi yang digunakan siswa adalah mengenali lingkungan sekitar terlebih dahulu setelah itu siswa diajak untuk mempromosikan produk yang telah dibuat. Dalam hal memasarkan produk mereka harus mengenali siapa target market kita, apa saja keunggulan dari produk kita, mengenali produk terlebih dahulu setelah itu kita dapat menyakinkan konsumen.

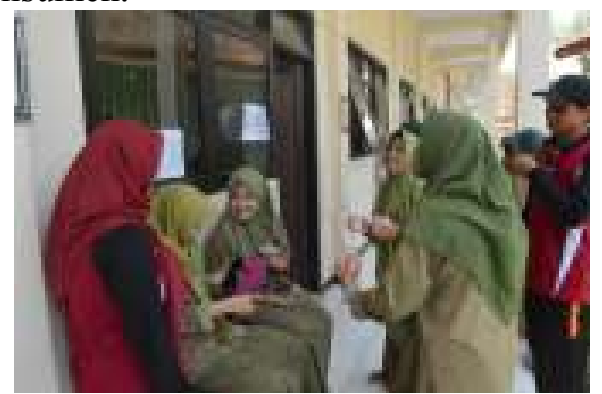

Gambar 11. Pemasaran Es Sarang Burung Cincau

3. Program Manajemen Keuangan
Wirausaha
Kegiatan selanjutnya adalah pelatihan manajemen keuangan yang benar yaitu siswa diajak untuk menghitung berapa biaya 
yang telah dikeluarkan untuk pembuatan es tersebut. Dalam melakukan sebuah usaha kitra wajib melakukan pencatatan biayabiaya apa saja yang kita keluarkan, berapa banyak barang digunakan dan total biaya yang dikelarkan untuk 1 kali produksi agar kita dapat menghitung sebuah harga diperlukannya pertimbangan dari biayabiaya yang kita keluarkan. Biaya adalah harga perolehan yang dikorbankan atau digunakan dalam rangka memperoleh penghasilan yang akan dipakai sebagai pengurang penghasilan (Supriyono, 1999). Selanjutnya, siswa diajak untuk menghitung harga pokok penjualan. Terakhir siswa diajak untuk menetapkan harga produk.

Siswa diajari penghitungan persentase laba yang dinginkan. Dalam penghitungan ini kita dapat mengetahui berapa keuntungan/kerugian dalam satu kali produksi apabila uang modal kembali dan biaya biaya sudah terbayarkan kita mendapatkan keuntungan. Apabila uang yang kita dapatkan lebih kecil dari modal yang kita keluarkan maka kita dikatakan rugi (Machfoedz; 2005).

Berdasarkan masing-masing hasil pelaksanaan kegiatan berikut ini pembahasannya:

\section{Gerakan Lingkungan}

Pendidikan lingkungan adalah sebuah kebutuhan yang tak terelakkan bila kita ingin mewujudkan masyarakat madani seperti yang dicita-citakan Hamzah (2013:37). Pentingnya pendidikan lingkungan sangatlah penting untuk, mengimbangi kemampuan intelektual yang di tanamkan oleh semua sekolah tak terkecuali MA Darul Ulum. Oleh karena itu tim KKN STKIP PGRI Pasuruan mengadakan program lingkungan yeng terdiri dari beberapa kegiatan, antara lain:

a. Kegiatan Sosialisasi Tanaman Toga

Kegiatan ini dilaksanakan karena kami mengetahui banyaknya manfaat dari tanaman toga. Adapun manfaat TOGA, meliputi sarana memperbaiki status gizi masyarakat, tanaman obat dikenal sebagai buah-buahan atau sayursayuran, sarana pelestarian alam apabila karena upaya budidaya mencegah kepunahan, sarana penyebaran gerakan penghijauan untuk daerah yang mengalami penggundulan karena dapat dianjurkan penyebarluasan tanaman obat pepohonan seperti pohon asam, kedaung, trengguli dan lainlain, dan sarana pemerataan pendapatan karena menyediakan bahan obat bagi keluarga yang dapat berfungsi sebagai sumber penghasilan keluarga.

b. Kegiatan sosialisasi pembuatan pot animal

Kegiatan ini dimulai dari menyiapkan peralatan dan bahanbahan yang dibutuhkan untuk memb uat pot animal. Setelah peralatan dan bahan-bahan yang dibutuhkan telah tersedia dilanjutkan dengan proses pembuatannya. Kegiatan ini bermanfaat untuk meningkatkan kreatifitas siswa dan juga bermanfaat untuk mengurangi limbah yang ada dilingkungan sekitar dengan cara mendaur ulang

c. Kegiatan Edukasi Teknik Static Solution Culture

Program kegiatan ini merupakan edukasi kepada seluruh warga sekolah tentang teknik static solution culture. Static solution culture memiliki pengertian budidaya hidroponik dengan air statis yang mana airnya diam dan tidak mengalir, merupakan teknik hidroponik yang akarnya secara terus-menerus akarnya tercelup air yang diletakkan pada wadah berisi larutan nutrien.

d. Kegiatan Pengelolaan Sampah Organik dan Nonorganik

Siswa diberikan pengetahuan tentang cara pengelompokan sampah dan cara pengelolaannya. Adapun upaya pengelolaan sampah dapat dilakukan dengan cara Reuse, Reduce, dan Recycle (3R) adalah kegiatan yang memperlakukan sampah dengan cara, menggunakan kembali, mengurangi dan mendaur ulang. 
Reuse (menggunakan kembali) yaitu penggunaan kembali sampah secara langsung, baik untuk fungsi yang sama maupun fungsi lain. Reduce (mengurangi) yaitu mengurangi segala sesuatu yang menyebabkan timbulnya sampah. Recycle (mendaur-ulang) yaitu memanfaatkan kembali sampah setelah mengalami proses pengolahan

e. Kegiatan Pengadaan Taman Sekolah Di Taman MA Darul Ulum terdapat batu taman, jalan setapak, peletakan batu alam, terdapat 2 jenis tong sampah dengan warna berbeda - beda, ornamen bebatuan dan semua itu termasuk dalam bidang keras. Sedangkan dalam bidang lunak seperti tanaman tanaman yang tumbuh disana contohnya cemara, pucuk merah, puring, rerumputan, manga, suruh, lee kwan yu dan banyak tanaman lainnya.

\section{Gerakan Sekolah}

Gerakan ini berupaya untuk mengembangkan budaya literasi yang berada di sekolah yaitu mading sekolah, administrasi perpustakaan, penjenamaan identitas kelas, dan desain grafis.

a. Mading bermanfaat sebagai media komunikasi termurah untuk menciptakan komunikasi antara pihak tertentu. Dengan adanya mading siswa dapat mendapatkan dan berbagi bermacam informasi. Dengan membaca mading wawasan dapat bertambah dan juga sebagai wadah kreatifitas. Siswa dapat mengembangkan keterampilan, berbagi informasi dan karya tulis lainnya. Sehingga mereka termotivasi untuk mengembangkan kemampuan mereka di bidang literasi.

b. Administrasi perpustakaan bermanfaat untuk melaksanakan layanan perpustakaan yang baik, mudah dan menarik agar pelajar tertarik untuk pergi ke perpustakaan. Manfaat lainya yaitu memberikan bimbingan membaca, menyediakan bahan bahan yang bermanfaat untuk meningkatkan kegiatan literasi sekolah. Dalam kegiatan ini juga dilakukan pemilihan duta perpustakaan yang bermanfaat untuk memotivasi pelajar untuk lebih aktif membaca di perpustakaan dan membantu dinas perpustakaan untuk meningkatkan minat baca warga sekolah.

c. Penjenamaan kelas untuk menguatkan identitas sekolah yang sudah maju dengan mendesain setiap kelas dengan ciri khas yang berbeda melalui pemberian identitas kelas menggunakan tokoh wali songo. Hal ini menunjukan bahwa madrasah tersebut meliki karakter tertentu sehingga menarik para orang tua untuk menyekolahkan anaknya di sekolah tersebut. Hal ini juga bermanfaat untuk mengenalkan siswa terhadap tokoh wali songo yang menjadi identitas kelas mereka.

d. Kegiatan desain grafis tidak lepas dari tujuan komersial dan pengekspresian seni yang ditunjukan melalui bentuk visual baik berupa hardfile maupun softfile. Kegiatan ini bermanfaat untuk mengenalkan dunia desain grafis kepada siswa sehingga merka dapat menerapkannya, mengenalkan siswa kepada aplikasi-aplikasi desain grafis dan menyiapkan siswa agar bisa menyampaikan pesan-pesan dalam bentuk grafis.

\section{Gerakan Kewirausahaan}

Kegiatan kewirausahaan berhubungan dengan kegiatan demo masak membuat minuman es susu jelly dan es sarang burung cinacu yang kemudian dipasarkan serta diberikan pembinaan dalam penyusunan keuangan hasil wirausaha.

a. Pelatihan pembuatan es susu jelly dan sarang burung cincau adalah membuat inovasi baru untuk menginspirasi siswa dalam minat berwirausaha. Manfaat lain dari kegiatan pembuatan es susu jelly dan es sarang burung dilaksanakan agar siswa dapat Memenuhi kebutuhan masyarakat disekolah. Kebutuhan yang dimaksud disini adalah kebutuhan tentang 
minuman yang layak untuk dikonsumsi.

b. Pemasaran produk bermanfaat untuk memberikan pelajaran kepada siswa agar mandiri dan dapat menghasilkan pendapatan sendiri siswa dapat memperluar wawasan dan menambah ilmu, siswa dapat mengembangkan bisnis dalam keseharian mereka, siswa dapat melatih jiwa kewirausahaan yang mereka miliki.

c. Berikutnya adalah bagaimana menyusun pengelolaan keuangan hasil usaha. Siswa juga dikenalkan tentang manajemen keuangan yang berfungsi untuk memperbesar keuntungan. memperbesar keuntungan adalah salah satu tujuan utama ketika menggunakan prinsip manajemen. Dengan memanfaatkan prinsip manajemen berbasis keuangan maka keuntungan yang dimiliki akan lebih besar.

\section{KESIMPULAN}

Program Kuliah Kerja Nyata yang dilaksanakan oleh tim KKN PGRI Pasuruan di MA Darul Ulum Karang Pandan, Rejoso terlaksana dengan cukup baik. Terdapat tiga program kerja yang telah dilakukan yaitu Program gerakan lingkungan, Program gerakan literasi dan Program kewirausahan. Dalam program ini Tim KKN PGRI Pasuruan melibatkan seluruh warga sekolah khususnya para siswa. Mereka memberikan tanggapan yang cukup baik. Mereka sangat antusias untuk mengikuti setiap program yang telah direncanakn. Program kerja yang diberikan kepada masyarakat sekolah dapat terealisasi dengan optimal dan lancer. Program kerja tersebut bertujuan untuk memberikan dukungan dan pengetahuan yang berdampak dampak positif masyarakat maupun lingkungan sekolah.

\section{SARAN}

Saran yang dapat kami berikan yaitu dengan adanya program ini diharapkan seluruh warga sekolah bisa menjadi pribadi yang peduli terhadap lingkungannya. Warga sekolah harus terus menjaga dan memelihara hasil dari setiap program yang telah terealisasikan. Warga sekolah juga harus bisa mengembangkan kemampuan dan kreatifitas yang telah diajarkan oleh tim KKN PGRI Pasuruan.

\section{UCAPAN TERIMA KASIH}

Penulis mengucapkan terima kasih kepada STKIP PGRI Pasuruan dan MA Darul Ulum Karangpandan Pasuruan yang telah memberikan kesempatan pengalaman mahasiswa dalam melaksanakan rangkaian program KKN. Serta terimakasih diberikan kepada Bapak Tristan Rokhmawan, S.S., M.Pd. Selaku Dosen Pendamping Lapangan dalam program ini.

\section{DAFTAR PUSTAKA}

[1] Christiawan, I (2017). Variasi Komposisi Sampah Berbasis Sosio Ekonomi Pemukim Pada Kompleks Perumahan di Kelurahan Banyuning. FHIS UNDIKSHA.

[2] Faizah, D. U. dkk. (2016) Panduan Gerakan Literasi Sekolah. Jakarta: Direktorat Jenderal Pendidikan Dasar dan Menengah Kementrian Pendidikan dan Kebudayaan.

[3] Hamzah, Syukri. 2013. Pendidikan Lingkungan: SekelumitWawasan . Bandung: RefikaAditama

[4] Harini. 2008. PenetapanHarga , MakroEkonomiPengantar. Jakarta: Pt Gramedia.

[5] Harryanto, R dkk. (2017). Gerakan Penghijauan DAS Citarum Hulu di Desa Cikoneng Kecamatan Cileunyin Kabupaten Bandung. Bandung : Universitas Padjajaran.

[6] Machfoech, Mahmud. 2005. PengantarPemasaran Modern. Yogyakarta. Upp Amp

[7] Means, B. (1993). Using Technology to Support Education Reform. USA: US Government Printing Office.

[8] Nursisto. 1999. Membina Majalah Dinding. Yogyakarta : Adicita Karya Nusa.

[9] Subekti, S. (2010). Pengelolaan Sampah Rumah Tangga 3R Berbasis Masyarakat. Prosiding SNST Fakultas Teknik, 1(1)

[10] Supriyono. Akuntansi Biaya. 1999. BPFE-YOGYAKARTA, Yogyakarta.

[11] Sutrisno, D. (2019). Laporan kuliah Kerja Magang (KKM) bagian Accounting Pada Loreta Shoes 
Jombang. Jombang: STIE PGRI DEWANTARA Jombang

[12] Weidarti, P. dkk. (2016) Desain Induk Gerakan Literasi Sekolah. Jakarta: Dirjen Disdakmen Kemendikbud RI.

[13] Widodo, HS. (1992). Majalah Dinding sebagai Pembinaan Kreativitas Siswa. Makalah disajikan dalam Diklat Pembuatan Majalah Dinsing bagi Para Guru di SD di Kecamatan Sumbefmanjing Wetan Kabupaten Malang. Malang: LPM IKIP MALANG.

[14] Yeager, E. A. dan Foster, S. J. (1996). The role of empathy in the development of historical understanding. Kertas kerja yang dibentangkan di College and Faculty Assembly, Washington, DC.

[15] Yulia, Yuyu. 2010. Pengembangan Koleksi. Jakarta : Universitas Terbuka.

[16] Zuliah, S. (2017). Bulan Penuh Berkah Untuk KKN UAD. Yogyakarta : Universitas Ahmad Dahlan 